\author{
LINE CECILIE ENGH \\ with STEFKA G. ERIKSEN and FRANCIS F. STEEN
}

\title{
Introduction \\ Homo renovatur de die in diem: Transforming Selves and Communities
}

This special issue of Acta ad archaeologiam et artium historiam pertinentia (from now on Acta) interrogates religious practices of reading, writing, praying, and engaging with texts, images, architecture, music, and ritual spaces in late antique Rome and medieval Europe. More specifically, it aims to analyze and deepen our understanding of how liturgy and religious practice modelled and modified selves and communities, how they shaped and transformed identities and built communities - both individual and collective, religious and lay.

The cover of the present issue shows a miniature from a large liturgical book, the Olivetan Gradual. This illuminated manuscript, produced for a monastery of the Olivetan order, a branch of the Benedictines, at Santa Maria di Baggio near Milan in the 1430s, has only just recently come to the attention of scholars. ${ }^{1}$ The large script, ornamental initials, illustrations, and musical notations indicate that the book was made for use in the choir (measuring $595 \mathrm{x}$ $435 \mathrm{~mm}$ ). An entire congregation of monks would have been able to see and read as they sang in choir: just as we see in the illustration from the manuscript itself, on the cover of this issue (fol. 9v). The illustration in question accompanies an antiphon, based on Psalm 50.9 (in the Vulgate numbering), which is a penitential psalm, in the voice of David. It reads: Asperges me ysopo et mundabor lavabis me et super nivem dealbabor ("Thou shalt sprinkle me with hyssop, and I shall be cleansed: thou shalt wash me, and I shall be made whiter than snow"). ${ }^{2}$ The antiphon was chanted during the sprinkling of believers with holy water at the start of the Mass on Sunday (except during Eastertide). In the miniature itself, we see the text of the antiphon Asperges me reduplicated in the open liturgical book in the centre of the image. The image shows the monks singing the antiphon while they are actually being sprinkled with holy water by the celebrant, symbolizing the cleansing of the participants.

\footnotetext{
${ }^{1}$ Since 2014 the manuscript, Beinecke MS 1184, is in the possession of Beinecke Rare Book and Manuscript Library at Yale, for digital access, go to: https://brbl-dl.library.yale.edu/vufind/Record/4281554?image_id=16037198; on the manuscript, see Bollati 2008.

${ }^{2}$ Douay-Rheimes translation.
} 
The illustration points to several aspects that are central to the studies presented in this issue. First, it points to the multimodal and multisensory character of the liturgy, evoking the sense of seeing (images, ornamentations, colours), the sense of hearing (chants, music, readings), the sense of smell (note the monk holding incense to the left in the image), as well as the sense of taste (the Eucharistic bread and wine) and touch (the sprinkled water and orchestrated movements in highly structured architectural spaces). Such synesthetic sensory experiences in the liturgy were designed to make the invisible visible and the ineffable effable, turning (divine) absence into (divine) presence. ${ }^{3}$

Second, it points to the performativity inherent in liturgy and religious practices. Engaging with texts, artifacts, and ritual spaces were performative events: they were supposed to effect something, to do something. In our Olivetan Gradual, we find that while the monks are vocalizing in chant their desire to be cleansed in the antiphon Asperges me, they are actually being sprinkled, enacting the psalmist's desire to be cleansed by God. The liturgy was an altogether spectacular case of representation; it not only effected what it signified but even, in the case of the central liturgical sacrament - the Eucharist - was what it signified. ${ }^{4}$

Third, the illustration points to the power of the choir as the nexus of a ritual space where the everyday constraints of time and space are systematically transcended: practices of reading, praying, and performing the liturgy are carefully orchestrated to transport its participants, empowering them to breach the boundaries between past, present, and future, heaven and earth. The liturgy does not simply commemorate past events; it stages these events into the present, nudging each participant into a new identity, a habitable subject position as an agent in an endlessly recurring drama. Architecturally, the space of the choir, the altar, and the church itself function as material anchors that confirm and support the narrative, easing the transition into an alternate reality, making the liturgical events present and accessible. This cyclical reenactment of the past, situating the monks as subjects within a divine drama, also positions them to contemplate its promise of a future fulfillment. By adopting the first-person voice (the Psalmic 'I'), the Olivetan monks in the illustration participated in the biblical past - that of the people of Israel or David himself. At the same time, they also projected themselves into an eschatological future: inside the church, the nave walls represent a starry sky, indicating that the choir is merging with the heavenly angelic choirs.

In the liturgy Christ was referred to as the new man (homo novus), who restored humanity back to its original state of prelapsarian innocence. Reworking and recharging the ancient Roman concept of homo novus (a self-made man: someone who achieved political, economic and civic advancement without lineage or dynastic advantages), Christian writers sometimes used the phrasing homo renovatur de die in diem ("the man [who is] renewed day by day", 2 Cor 4.16, cf. Col 3.9-10), to indicate the transformation from "carnal life", which is bound to the world and worldly pleasures and ambitions, to "spiritual life". In its Christianized version, transformation into homo novus is Christomimetic - and carries fundamental notions of an ongoing, dynamic process of re-creation or re-formation. For early and medieval Christians, the reference to "day by day" (de die in diem) hinted at the steady rhythm of the cyclical liturgical calendar and suggested its intersection with eternal time and spiritual reality.

\footnotetext{
${ }^{3}$ Palazzo 2014.

${ }^{4}$ Ladner 1979.
} 
But what were the underlying assumptions and cognitive processes that made the transformation of selves and communities - the creation of a new self (homo novus) - a conceivable project, with actual effects? How were liturgy and religious practices supposed to accomplish this? Was there an explicit purpose? What were the social processes that brought these practices about - designed them, assembled them, deployed them?

The essays in this special issue of Acta address these questions. The essays complement each other by covering a wide range of sources: literary and theological texts, manuscripts, art and architecture, and ritual spaces. They span historical periods, from Late Antiquity to the Renaissance, and geographical regions, from Rome and Italy to France, Jerusalem, and Scandinavia. The essays deploy an array of approaches, some theoretically driven and others more empirical. Several of the contributors apply perspectives and concepts from cognitive science. Many more use terms like 'performance', 'play', 'enactment', and 'staging', which carry more or less distinct theoretical implications. These terms provide scholars of religious practice with useful tools, albeit aligning liturgy and theatre in a way that early and medieval Christians would flinch at. The essays in this volume of Acta pursue questions of inferences arising from the sources, implicit and explicit aims, connections, and mappings, asking about communicative intent and communicative effect, and using both etic and emic approaches. A few of the essays also ask about the medieval experience of religious ritual, based on the available evidence, from diverse viewpoints. Can we, as scholars, access something of these multilayered and multimodal experiences? Can we promote a richer analytical engagement with our sources?

All the essays in this volume address the question of transformation and/or cognitive and emotional engagement. All essays, moreover, engage in one or two or all of the three themes indicated above: 1) multimodal/multisensory perception, 2) performativity, and 3) identities across time and space.

The volume is divided into two parts, each with a loose chronological order. The first part, 'Rewiring Romans', focuses on Rome. In many ways, Rome offers a paradigmatic model of societal and cultural transformation as it transformed from the capital of the Empire to the capital of the Church, reinterpreting its past and its identity. The essays connect these transformations of selves and communities to religious practices from the Mithras cult to Christian liturgy and to the medieval papacy in Rome.

Taking us back into the twilight of ancient Rome, SANDRA BLAKELY draws on pragmatic cognitive science, rooted in Dewey's epistemology and models of distributed cognition, to offer new hypotheses for the emergence and decline of the Mithraic rites. This model of the rites suggests dynamics with Christianity focused less on theology than on responsiveness to the economic and social transformations of the fourth and fifth centuries CE, suggesting that the end of Mithraism emerged as a result, not of the cult's inability to transform itself, but to effectively transform the celebrant's experience into the needed tools for a dramatically changed world.

JOHN F. ROMANO focuses on Ordo Romanus XI, a liturgical script that describes the process for performing baptism, to analyze the behavior, attitudes, and identity of seventhcentury Romans, both on individual and collective levels. Romano shows that in early Christian Rome the liturgy and especially the rite of baptism cemented the relationship between the 
laity and clergy, and tied the Romans into biblical history, whereby they assumed the mantle of the ancient Israelites and became God's chosen people.

Moving us outside the physical city of Rome, ARTHUR WESTWALL discusses Carolingian manuscripts that contain ordines romani, 'stage directions' for the liturgy, distinguished by their reference to the practices of the Church of Rome. Westwall examines how Carolingian clergy and liturgical commentators provided choreography for the correct liturgy, mapping Roman identities and the idealized topography of Rome onto their own cities and churches, as an imaginative recollection of Rome.

Discussing spaces, communities, and liturgy in S. Maria in Trastevere ("Basilica Julii") in medieval Rome, DALE KINNEY demonstrates that liturgical transformation was a two-way process, in which liturgy was the object as well as the agent of change. The original nonhierarchical layout was replaced by one in which celebrants were elevated above the congregation, women were segregated from men, and higher-ranking lay people were accorded places of honor distinct from those of lesser stature, in line with the requirements of the ninthcentury papal stational liturgy. She shows how social distinctions among several groups high clergy, canons, the lay congregation - were embedded physically and architecturally, and reinforced the communal identity of each.

Turning to the liturgy of the Gregorian Reforms, WIM VERBAAL argues that the liturgy functioned as a means to re-imagine Rome and to strengthen the popes' own role with respect to ecclesiastical and secular opponents. Analyzing the Liber politicus by Benedict the Canon (around 1140), Verbaal discusses how Innocent II used liturgy to shape the political role of the papacy and to achieve and express papal supremacy.

Still within the context of the papacy, JOËLLE ROLLO-KOSTER demonstrates how liturgists responded with the tools of their trade to the Great Western Schism (1378-1417), the critical phase when two papacies competed with each other. She analyzes how Pierre Ameil, a contemporary of the Schism and the author of a ceremonial book or ordo, attempted to reconstruct ecclesiastical unity by developing a new rubric centered on the rituals surrounding the pope's death, building continuity on the embalmed papal corpse rather than on the College of Cardinals.

The second part of the volume, 'Trajectories of Identities', traces the impact of liturgy and religious practices on selves and communities in medieval Latin Christendom focalizing on different groups in geographically diverse areas. With these essays, we move from centre to periphery, geographically as well as religiously and socially: from the core areas of Christian Europe (France, Italy, and Jerusalem) to the peripheral Scandinavian North, and, in parallel, from groups of religious elites (Cistercians, Dominicans, Franciscans), via clerics, to lay people and even children, positioned at the very bottom of the spiritual hierarchy. In overview, the essays suggest that processes of transforming identities, of reinterpreting the past, of (re-)memorization, and of individual and collective conversion were adapted to different contexts. In a broad sense, they suggest that what is at stake here are more general processes of cultural learning and acculturation.

LINE CECILIE ENGH uses analytical concepts from cognitive science to explore and deepen our understanding of how medieval monastics imagined themselves as characters within biblical narratives. She argues that Cistercian monks - and in particular Bernard of Clairvaux - used techniques of imaginative immersion to enter and blend themselves into 
biblical viewpoints and events, thereby engaging the monks in epistemically and personally transformative experiences, which served to build community and to enculture monks and adult converts.

Turning to the Dominicans, MARIKA RÄSÄNEN analyzes the Office of Translatio, the translation of Thomas' relics to Toulouse, where Dominic had founded the Order of Preachers. The office not only put the saint's real presence on display, where people could touch and smell him, see him and hear him by their side. Räsänen proposes that the Office of Translatio inaugurated Thomas as the leader of a new era and the saviour of good Christians in a Christlike manner, which offered a new interpretation of the new apostles, the Dominicans, and the construction of an eschatological self-understanding for Dominican identity.

VALENTINA COVACI examines the Franciscans in Jerusalem through two previously unexamined liturgical texts (Missa devota ad recuperandam Terram Sanctam and Ad Sanctum Sepulcrum Domini introitus). Positioning the texts in the historical context of fifteenthcentury Jerusalem, when the Franciscan friars were the only Latin clergy allowed to serve at the Holy Places, she demonstrates the friars' efforts at a militant memorialization of the deeds of the crusader kings, celebrated as liberators of the Holy Land.

Young clerics figure prominently in NILS HOLGER PETERSEN's analysis of the liturgical play, Danielis ludus (Play of Daniel). Petersen analyzes the play as a liturgical ritual transforming the (corporate) identity of the young clerics who were involved in its performance, shedding light on the 'ritual technologies' of medieval liturgical ceremonies more generally.

Moving us into medieval Scandinavia, RAKEL DIESEN gives a reading of Nordic hagiographical stories of miraculously cured children. Diesen's analyses focus on events that transpired during prayers and services and show how children were seen and heard in liturgical spaces, adding to our understanding of multisensory and multimodal experiences in religious practices as well as the sensory experiences of medieval children.

Giving a fresh reading of an Old Norse translation of the pan-European legend about Barlaam, STEFKA G. ERIKSEN suggests that the reading of literature may have served as a tool assisting in the transformation of the self for lay readers in medieval Norway, in a way similar to the liturgy. She argues that the text foregrounded the Christian quadriga model through the saga's content, its narratological structure, and the mise en page of the manuscript, which may have served to teach this model to its readers, i.e. members of the upper social class in medieval Norway during the second half of the thirteenth and the beginning of the fourteenth century.

Visual engagement and emotional response among the laity are also central to LASSE HODNE's discussions of frontal portraits of Christ from the Renaissance. Discussing paintings by Hans Memling, Hodne shows how Memling's systematic distinction between sacred and profane, using the frontal view only for representations of Christ, can be explained by reference to psychological studies on the effects and values usually associated with the frontal view of a face.

The essays in this volume demonstrate that liturgy and religious practices served as vectors for framing, structuring and reinterpreting material and mental surroundings, others and oneself. In light of the deep structural changes and cultural upheavals that took place in this period - in Italy and Rome from the fifth to the seventh century, in the North during the 
twelfth and thirteenth centuries - we emphasize the transformative potential of religious practices. By teasing out the broader social and cognitive processes inherent in religious practices and liturgy, we may gain better insight into cultural resilience and into the human resources that are available as we face modern predicaments and the recurring challenges posed by crises and cultural and social transformations. Like the ancient Roman homo novus, the Christian homo novus challenged and redefined predefined patterns. Homo novus signalized a change of narrative (or 'possibility spaces'): re-formulation of goals, re-identification of obstacles and resources, and development of new strategies. Thus, in its broader outlook, the volume gestures towards more encompassing cognitive and communicative processes that underlie cultural change.

Line Cecilie Engh

University of Oslo

l.c.engh@ifikk.uio.no

Stefka G. Eriksen

Norwegian Institute for Cultural Heritage Research

stefka.eriksen@niku.no

Francis F. Steen

University of California Los Angeles

steen@commstds.ucla.edu 


\section{BIBLIOGRAPHY}

Bollati M. 2008: The Olivetan Gradual: Its Place in Fifteenth-century Lombard Manuscript Illumination, London; Chicago; Paris.

Ladner G.B. 1979: "Medieval and Modern Understanding of Symbolism: A Comparison", Speculum 54, 223-56.
Palazzo É. 2014: L'Invention chrétienne des cinq sens dans la liturgie et l'art au Moyen Âge, Paris. 